\title{
A review on synthesis of Cadmium and Manganese oxide nanoparticles with its vitro applications
}

\author{
Ashutosh Dixit ${ }^{1}$, Renu Bala ${ }^{1}$, Dr.Bhawna Pareek ${ }^{1 *}$, Ashun Chaudhary ${ }^{2}$, Dr.Vivek Sheel Jaswal ${ }^{3}$ \\ 1- P.hD Scholar, 1*- Professor, 2- Assistant Professor, 3- Assistant Professor
}

\author{
${ }^{1}$ Department of Chemistry, Maharishi Markandeshwar (Deemed to be University), Mullana-133207, Ambala, \\ India, ${ }^{2}$ Department of Plant Science (Botany), Temporary Academic Block Shahpur, Central University of \\ Himachal Pradesh, Dharamshala, H.P, India, ${ }^{3}$ PG Department of Chemistry, SMDRSD College, Pathankot
}

145001, Punjab, India.

*Author for correspondence (Email: dr.pareekbhawna@gmail.com)

\begin{abstract}
Nanoparticles have a greater surface area and thus precise characteristics in the implementation and development of nano-specifically dimensioned materials. The Photocatalytic degradation properties of cadmium oxide $(\mathrm{CdO})$ and manganese oxide $(\mathrm{MnO})$ nanoparticles $(\mathrm{NPs})$ vary significantly than those of standard products due to their large bandwidth and energy binding. These nanoparticles have potential applications in antibacterial, antioxidant, antimicrobial etc. these nanoparticles were produced using a number of ways such as sol-gel, co-precipitation, green synthesis, microwave etc.
\end{abstract}

Keywords: CdO NPs, MnO NPs, Methods, Activities, Sizes

\section{Introduction:}

Nanomaterials possessing a length scale smaller than $100 \mathrm{~nm}$, have gained increasing interest because not just to their important research significance but also to the possible applications that result from their interesting magnetic, electrical and catalytic capabilities [1]. Many of the most appealing inorganic minerals is manganese dioxide $\left(\mathrm{MnO}_{2}\right)$. Manganese dioxide is a transition metal oxide of P-type semiconductors with a band gap of $3.3 \mathrm{eV}$ and $3.8 \mathrm{eV}$ [2]. Manganese dioxide nanoparticles could be employed in a variety of applications, including electrodes, catalysis, sensors and optoelectronics [3]. Because of its high theoretical capacity, low cost, and unique features, $\mathrm{MnO}$ and $\mathrm{MnO}_{2}$ nanoparticles have piqued attention as anode materials in lithium ion batteries [4]. The hydrothermal approach [5], sol-gel synthesis [6], wet chemical approach [7], pulsed laser deposition method [8], and precursor approach [9] have all been used to create manganese oxide nanomaterials with diverse forms and outstanding characteristics. Manganese oxides, such as $\mathrm{MnO}_{2} \mathrm{Mn}_{5} \mathrm{O}_{8}$, $\mathrm{Mn}_{2} \mathrm{O}_{3}$, and $\mathrm{Mn}_{3} \mathrm{O}_{4}$, have diverse structures and can be employed in a range of applications. Mn-oxide NPs may hold a lot of promise for long-term nanotechnology. The green production use and future prospects of Mn NPs are also the focus of this review, different techniques of green synthesis of Mn NPs have been researched and pretended, including synthesis using plant extract, synthesis using microorganism and low-temperature synthesis of Mn NPs. Each methods structure and size of green produced Mn NPs was compared. Different approaches of green generated Mn NPs were also discussed. In addition, the prospects of green synthesis and characterization of green generated Mn NPs are discussed. Additionally, many applications for green produced Mn NPs, as well as potential uses for green synthesized Mn NPs are discussed [10]. Similarly, due to its n-type metallic oxide feature, cadmium oxide $(\mathrm{CdO})$ has been discovered to be useful in Photocatalytic application such as solar cells, photovoltaics, flat displays, and sensors with explicit and implicit band gaps of $2.3 \mathrm{eV}$ and $1.36 \mathrm{eV}$ respectively [11]. Cadmium oxide nanostructures are a low-cost [12], chemically stable, and comparatively nontoxic metal oxide semiconductor nanomaterials with applications in photo catalysis [13], gas sensors [14], transistors [15], transparent electrode [16], and solar cells [17], drug delivery [18], antibacterial medicines [19], optics [20], and environmental cleanup [21] are only a few of the applications. Because of their physiochemical affinity with the human body, CdO-NPs have remarkable biological, chemical and physical features [22]. Furthermore, the various properties of CdO-NPs make them extremely powerful for commercial applications [23]. Aside from the numerous benefits and applications of metallic NPs, the anti-microbial application represents a significant advancement in the fight against antibiotic-resistant bacterial infection [24]. 


\begin{tabular}{|c|c|c|c|c|c|c|c|}
\hline $\begin{array}{l}\text { S. } \\
\mathbf{N} \\
\mathbf{O}\end{array}$ & $\begin{array}{l}\text { ME } \\
\text { TAL }\end{array}$ & $\begin{array}{l}\text { SI } \\
\text { ZE }\end{array}$ & SHAPE & $\begin{array}{l}\text { METHOD } \\
\text { S }\end{array}$ & $\begin{array}{l}\text { CHARCATE } \\
\text { RIZATION }\end{array}$ & $\begin{array}{l}\text { APPLIC } \\
\text { ATION }\end{array}$ & REFERENCE \\
\hline 1 & $\mathrm{Cd}$ & $29 \mathrm{~nm}$ & $\begin{array}{l}\text { Rod- } \\
\text { shaped }\end{array}$ & $\begin{array}{l}\text { Chemical } \\
\text { precipitatio } \\
\text { n method }\end{array}$ & $\begin{array}{l}\text { XRD, FESEM, UV-vis, } \\
\text { and FTIR analysis }\end{array}$ & $\begin{array}{l}\text { Photocatalyt } \\
\text { ic activity }\end{array}$ & $\begin{array}{l}\text { M. Vidhya et al } \\
(2017)^{25}\end{array}$ \\
\hline 2 & $\mathrm{Cd}$ & $25 \mathrm{~nm}$ & $\begin{array}{l}\text { Spherical } \\
\text { shape }\end{array}$ & $\begin{array}{l}\text { Microwave } \\
\text { method }\end{array}$ & & $\begin{array}{l}\text { Photocatalyt } \\
\text { ic and } \\
\text { antimicrobia } \\
\text { l activity } \\
\end{array}$ & $\begin{array}{l}\text { Kannan k et al } \\
(2020)^{26}\end{array}$ \\
\hline 3 & $\mathrm{Cd}$ & $58 \mathrm{~nm}$ & $\begin{array}{l}\text { Spherical } \\
\text { shape }\end{array}$ & $\begin{array}{l}\text { Co- } \\
\text { precipitatio } \\
\text { n method }\end{array}$ & $\begin{array}{l}\text { UV-vis, spectroscopy, } \\
\text { FTIR, SEM, XRD, EDX }\end{array}$ & $\begin{array}{l}\text { Antibacteria } \\
1 \text { activity }\end{array}$ & $\begin{array}{l}\text { Azam Z et al } \\
(2020)^{27}\end{array}$ \\
\hline 4 & $\mathrm{Cd}$ & $41 \mathrm{~nm}$ & Rod-shaped & $\begin{array}{l}\text { Green } \\
\text { synthesis }\end{array}$ & $\begin{array}{l}\text { DSC, DTA, and TGA, } \\
\text { XRD, EDX, FTIR }\end{array}$ & & $\begin{array}{l}\text { H. } \\
\text { KohilaSubathr } \\
\text { a Christy et al } \\
(2020)^{28}\end{array}$ \\
\hline 5 & $\mathrm{Cd}$ & $\begin{array}{l}\text { Approxi } \\
\text { mately } \\
5 \mathrm{~nm}\end{array}$ & $\begin{array}{l}\text { Spherical } \\
\text { shape }\end{array}$ & $\begin{array}{l}\text { Green } \\
\text { synthesis }\end{array}$ & $\begin{array}{l}\text { XRD, TEM, SEM, FTIR } \\
\text { and EDX }\end{array}$ & $\begin{array}{l}\text { antimicrobia } \\
1 \text { activity }\end{array}$ & $\begin{array}{l}\text { Mohammed } S . \\
\text { Alsaggaf et al } \\
(2020)^{29}\end{array}$ \\
\hline 6 & $\mathrm{Cd}$ & $24 \mathrm{~nm}$ & $\begin{array}{l}\text { Spherical } \\
\text { shape }\end{array}$ & $\begin{array}{l}\text { Laser } \\
\text { ablation }\end{array}$ & $\begin{array}{l}\text { FESEM, HRTEM, } \\
\text { EDX, UV-vis, and FTIR }\end{array}$ & & $\begin{array}{l}\text { Ayman } \\
\text { Mostafa } \text { et al } \\
(2017)^{30}\end{array}$ \\
\hline 7 & $\mathrm{Cd}$ & $28 \mathrm{~nm}$ & $\begin{array}{l}\text { Spherical } \\
\text { shape }\end{array}$ & $\begin{array}{l}\text { Hydrother } \\
\text { mal method }\end{array}$ & $\begin{array}{l}\text { XRD, FESEM, UV-vis, } \\
\text { and FTIR analysis }\end{array}$ & $\begin{array}{l}\text { Photocatalyt } \\
\text { ic activity }\end{array}$ & $\begin{array}{l}\text { Naveed Akhtar } \\
\text { Shad et al } \\
(2019)^{31}\end{array}$ \\
\hline 8 & $\mathrm{Cd}$ & $\begin{array}{l}\text { 73-94 } \\
\mathrm{nm}\end{array}$ & $\begin{array}{l}\text { Regular } \\
\text { shape }\end{array}$ & $\begin{array}{l}\text { Green } \\
\text { synthesis }\end{array}$ & FTIR, UV-vis, SEM & $\begin{array}{l}\text { Antibacteria } \\
1 \text { activity }\end{array}$ & $\begin{array}{l}\text { Irfan Ijaz et al } \\
(2020)^{32}\end{array}$ \\
\hline 9 & $\mathrm{Cd}$ & $22 \mathrm{~nm}$ & $\begin{array}{l}\text { Spherical } \\
\text { shape }\end{array}$ & $\begin{array}{l}\text { Green } \\
\text { synthesis }\end{array}$ & $\begin{array}{l}\text { XRD, FESEM, HRTEM } \\
\text { and FTIR }\end{array}$ & $\begin{array}{l}\text { Antibacteria } \\
1 \text { activity }\end{array}$ & $\begin{array}{l}\text { k. Karthik et al } \\
(2017)^{33}\end{array}$ \\
\hline 10 & $\mathrm{Cd}$ & $\begin{array}{l}\text { approxi } \\
\text { mately } \\
14 \mathrm{~nm}\end{array}$ & $\begin{array}{l}\text { Spherical } \\
\text { shape }\end{array}$ & $\begin{array}{l}\text { Hydrother } \\
\text { mal method }\end{array}$ & $\begin{array}{l}\text { XRD, FESEM, UV-vis, } \\
\text { FTIR }\end{array}$ & $\begin{array}{l}\text { Photocatalyt } \\
\text { ic activity }\end{array}$ & $\begin{array}{l}\text { Sumeet Kumar } \\
\text { et al }(2016)^{34}\end{array}$ \\
\hline 11 & $\mathrm{Cd}$ & $\begin{array}{l}\text { Approxi } \\
\text { mately } \\
22 \mathrm{~nm}\end{array}$ & $\begin{array}{l}\text { Spherical } \\
\text { shape }\end{array}$ & $\begin{array}{l}\text { Laser } \\
\text { ablation }\end{array}$ & $\begin{array}{l}\text { IR, UV-vis, XRD, TEM, } \\
\text { SEM, and EDX }\end{array}$ & & $\begin{array}{lr}\text { Eman } & A . \\
\text { Mwafy et al } \\
(2019)^{35}\end{array}$ \\
\hline 12 & $\mathrm{Cd}$ & $\begin{array}{l}28.92 \\
\text { and } \\
44.95 \\
\mathrm{~nm} \\
\end{array}$ & $\begin{array}{l}\text { Stick-like } \\
\text { morpholog } \\
\text { y }\end{array}$ & $\begin{array}{l}\text { Sol-gel } \\
\text { method }\end{array}$ & $\begin{array}{l}\text { XRD, FESEM, HRTEM } \\
\text { and FTIR }\end{array}$ & & $\begin{array}{l}Y N \text { Permana } \\
\text { et al }(2017)^{36}\end{array}$ \\
\hline 13 & $\mathrm{Cd}$ & $4-8 \mathrm{~nm}$ & $\begin{array}{l}\text { Spherical } \\
\text { shape }\end{array}$ & $\begin{array}{l}\text { Co- } \\
\text { precipitatio } \\
\text { n method } \\
\text { and } \\
\text { hydrotherm } \\
\text { al method }\end{array}$ & $\begin{array}{l}\text { UV, FTIR, HRTEM, } \\
\text { XRD, XPS, AFM, and } \\
\text { BET }\end{array}$ & $\begin{array}{l}\text { Antibacteria } \\
1 \text { activity }\end{array}$ & $\begin{array}{l}\text { Sourav } \\
\text { Sadhukhanet et } \\
\text { al }(2019)^{37}\end{array}$ \\
\hline 14 & $\mathrm{Cd}$ & $\begin{array}{l}39.73 \\
\mathrm{~nm}\end{array}$ & $\begin{array}{l}\text { Spherical } \\
\text { shape }\end{array}$ & $\begin{array}{l}\text { Co- } \\
\text { precipitatio } \\
\text { n method }\end{array}$ & $\begin{array}{l}\text { FTIR, XRD, SEM, with } \\
\text { EDAX and UV-vis }\end{array}$ & $\begin{array}{l}\text { antimicrobia } \\
1 \text { activity }\end{array}$ & $\begin{array}{l}\text { D. Durga Vijay } \\
\text { Karthik et al } \\
(2014)^{38}\end{array}$ \\
\hline 15 & $\mathrm{Cd}$ & $\begin{array}{l}10-32 \\
\mathrm{~nm}\end{array}$ & $\begin{array}{l}\text { Spherical } \\
\text { shape }\end{array}$ & $\begin{array}{l}\text { Green } \\
\text { synthesis }\end{array}$ & $\begin{array}{l}\text { XRD, FESEM, HRTEM } \\
\text { and FTIR }\end{array}$ & $\begin{array}{l}\text { Cytotoxic } \\
\text { and } \\
\text { genotoxic } \\
\text { activity }\end{array}$ & $\begin{array}{l}\text { E. Demir et al } \\
(2020)^{39}\end{array}$ \\
\hline
\end{tabular}




\begin{tabular}{|c|c|c|c|c|c|c|c|}
\hline 16 & $\mathrm{Cd}$ & $35 \mathrm{~nm}$ & $\begin{array}{l}\text { Spherical } \\
\text { shape and } \\
\text { irregular }\end{array}$ & $\begin{array}{l}\text { Green } \\
\text { synthesis }\end{array}$ & $\begin{array}{l}\text { UV-vis, FESEM, TEM, } \\
\text { XRD }\end{array}$ & & $\begin{array}{l}\text { JavadkarimiAn } \\
\text { deani et al } \\
(2013)^{40}\end{array}$ \\
\hline 17 & $\mathrm{Cd}$ & $25 \mathrm{~nm}$ & & $\begin{array}{l}\text { Sol-gel } \\
\text { method }\end{array}$ & $\begin{array}{l}\text { SAED, EDX, XRD, } \\
\text { TEM, SEM }\end{array}$ & & $\begin{array}{l}\text { B. Goswami et } \\
\text { al }(2015)^{41}\end{array}$ \\
\hline 18 & $\mathrm{Cd}$ & $8 \mathrm{~nm}$ & $\begin{array}{l}\text { Quasi- } \\
\text { spherical } \\
\text { shape }\end{array}$ & $\begin{array}{l}\text { Green } \\
\text { synthesis }\end{array}$ & $\begin{array}{ll}\text { HRTEM, EDS, } & \text { XRF, } \\
\text { XRD, ATR, } & \text { FTIR } \\
\text { Raman, XPS } & \\
\end{array}$ & & $\begin{array}{l}\text { F.T. Thema et } \\
\text { al }(2015)^{42}\end{array}$ \\
\hline 19 & $\mathrm{Mn}$ & $\begin{array}{l}25-30 \\
n m\end{array}$ & & $\begin{array}{l}\text { Co- } \\
\text { precipitatio } \\
\text { n method }\end{array}$ & UV-vis, XRD, FTIR & & $\begin{array}{l}\text { Harish Kumar } \\
\text { et al }(2013)^{43}\end{array}$ \\
\hline $\begin{array}{l}2 \\
0\end{array}$ & $\mathrm{Mn}$ & $\begin{array}{l}40.5-70 \\
\mathrm{~nm}\end{array}$ & $\begin{array}{l}\text { Spherical } \\
\text { shape }\end{array}$ & $\begin{array}{l}\text { Co- } \\
\text { precipitatio } \\
\text { n method }\end{array}$ & $\begin{array}{l}\text { XRD, FESEM, HRTEM } \\
\text { and FTIR }\end{array}$ & $\begin{array}{l}\text { antimicrobia } \\
1 \text { activity }\end{array}$ & $\begin{array}{l}\text { Elsa Cherian } \\
\text { et al }(2016)^{44}\end{array}$ \\
\hline 21 & $\mathrm{Mn}$ & $23.7 \mathrm{~nm}$ & $\begin{array}{l}\text { Tetragonal } \\
\text { shape }\end{array}$ & $\begin{array}{l}\text { Green } \\
\text { synthesis }\end{array}$ & $\begin{array}{l}\text { UV-vis, XRD, FTIR, } \\
\text { SEM }\end{array}$ & $\begin{array}{l}\text { Antibiofilm } \\
\text { and } \\
\text { antioxidant } \\
\text { activity }\end{array}$ & $\begin{array}{l}\text { KeerthanaSiva } \\
\text { nesan et al } \\
(2017)^{45}\end{array}$ \\
\hline 22 & $\mathrm{Mn}$ & $33 \mathrm{~nm}$ & $\begin{array}{l}\text { Regular } \\
\text { shape }\end{array}$ & $\begin{array}{l}\text { Co- } \\
\text { precipitatio } \\
\text { n method }\end{array}$ & $\begin{array}{l}\text { FTIR, UV-vis, } \\
\text { TGA/DSC, XRD, SEM- } \\
\text { EDX, TEM and BET }\end{array}$ & & $\begin{array}{l}\text { Taimur Athar } \\
\text { et al }(2012)^{46}\end{array}$ \\
\hline 23 & $\mathrm{Mn}$ & $31.7 \mathrm{~nm}$ & $\begin{array}{l}\text { Hexagonal } \\
\text { shape }\end{array}$ & $\begin{array}{l}\text { Solid state } \\
\text { reaction } \\
\text { route }\end{array}$ & UV-vis, XRD, FTIR & & $\begin{array}{l}\text { VikaskumarVe } \\
\text { rma et al } \\
(2018)^{47}\end{array}$ \\
\hline 24 & $\mathrm{Mn}$ & $\begin{array}{l}13.50 \\
\mathrm{~nm}\end{array}$ & $\begin{array}{l}\text { Irregular } \\
\text { shaped }\end{array}$ & $\begin{array}{l}\text { Green } \\
\text { synthesis }\end{array}$ & $\begin{array}{l}\text { XRD, } \\
\text { HRTEM, FTIR }\end{array}$ & & $\begin{array}{l}\text { Nur Oktri } \\
\text { Mulya Dewi et } \\
\text { al }(2020)^{48}\end{array}$ \\
\hline 25 & $\mathrm{Mn}$ & $\begin{array}{lr}22 & \mathrm{~nm}, \\
18 & \mathrm{~nm} \\
\text { and } & 16 \\
\mathrm{~nm} & \\
\end{array}$ & $\begin{array}{l}\text { Sphere } \\
\text { shaped }\end{array}$ & $\begin{array}{l}\text { Green } \\
\text { synthesis }\end{array}$ & FTIR, XRD and FESEM & $\begin{array}{l}\text { Antibacteria } \\
1 \text { activity }\end{array}$ & $\begin{array}{l}\text { Naveen } \\
\text { Chandra Josh } \\
\text { et al }(2020)^{49}\end{array}$ \\
\hline 26 & $\mathrm{Mn}$ & $\begin{array}{lr}20 & \mathrm{~nm} \\
\text { and } & 22 \\
\mathrm{~nm} & \\
\end{array}$ & Ball shaped & $\begin{array}{l}\text { Green } \\
\text { synthesis }\end{array}$ & $\begin{array}{l}\text { UV-vis, XRD, FTIR, } \\
\text { DSC }\end{array}$ & & $\begin{array}{l}\text { Yikal Dessie et } \\
\text { al }(2020)^{50}\end{array}$ \\
\hline 27 & $\mathrm{Mn}$ & $32 \mathrm{~nm}$ & $\begin{array}{l}\text { Spherical } \\
\text { shape }\end{array}$ & $\begin{array}{l}\text { Green } \\
\text { Synthesis }\end{array}$ & $\begin{array}{l}\text { UV-vis, XRD, FTIR, } \\
\text { SEM }\end{array}$ & & $\begin{array}{l}\text { Mahsa Souri et } \\
\text { al (2018) }\end{array}$ \\
\hline 28 & $\mathrm{Mn}$ & $\begin{array}{l}17-32 \\
\mathrm{~nm}\end{array}$ & $\begin{array}{l}\text { Spherical } \\
\text { shape }\end{array}$ & $\begin{array}{l}\text { Green } \\
\text { Synthesis }\end{array}$ & $\begin{array}{l}\text { UV-vis, XRD, FTIR, } \\
\text { PSA, SEM, EDAX and } \\
\text { HRTEM }\end{array}$ & $\begin{array}{l}\text { antimicrobia } \\
1 \text { activity }\end{array}$ & $\begin{array}{l}\text { R. Manjula et } \\
\text { al }(2019)^{52}\end{array}$ \\
\hline 29 & $\mathrm{Mn}$ & $4-18 \mathrm{~nm}$ & $\begin{array}{l}\text { Spherical } \\
\text { shape }\end{array}$ & $\begin{array}{l}\text { Green } \\
\text { Synthesis }\end{array}$ & $\begin{array}{l}\text { UV-vis, XRD, FTIR, } \\
\text { SEM }\end{array}$ & & $\begin{array}{l}\text { A K M Atique } \\
\text { Ullah et al } \\
(2018)^{53}\end{array}$ \\
\hline 30 & $\mathrm{Mn}$ & $\begin{array}{l}29 \text { and } \\
6 \mathrm{~nm}\end{array}$ & $\begin{array}{l}\text { Nanorod } \\
\text { shape }\end{array}$ & $\begin{array}{l}\text { Simple } \\
\text { microwave } \\
\text { method }\end{array}$ & $\begin{array}{l}\text { HRTEM, XRD, FTIR, } \\
\text { FESEM }\end{array}$ & & $\begin{array}{l}\text { Veeman } \\
\text { Sannasi et al } \\
(2020)^{54}\end{array}$ \\
\hline 31 & $\mathrm{Mn}$ & $8-15 \mathrm{~nm}$ & $\begin{array}{l}\text { Spherical } \\
\text { shape }\end{array}$ & $\begin{array}{l}\text { Green } \\
\text { synthesis }\end{array}$ & $\begin{array}{l}\text { TEM, XRD, BET, XPS, } \\
\text { VSM }\end{array}$ & & $\begin{array}{l}\text { Adina } \\
\text { Stegarescu } \\
\text { al }(2019)^{55}\end{array}$ \\
\hline 32 & $\mathrm{Mn}$ & $\begin{array}{l}20-50 \\
n m\end{array}$ & $\begin{array}{l}\text { Needle like } \\
\text { shape }\end{array}$ & $\begin{array}{l}\text { Co- } \\
\text { precipitatio } \\
\text { n method }\end{array}$ & $\begin{array}{l}\text { TEM, UV-vis, Raman, } \\
\text { XRD }\end{array}$ & $\begin{array}{l}\text { Supercapaci } \\
\text { tor } \\
\text { capacitance }\end{array}$ & $\begin{array}{l}\text { Sheng Chen et } \\
\text { al }(2010)^{56}\end{array}$ \\
\hline 33 & $\mathrm{Mn}$ & $\begin{array}{l}40-70 \\
\mathrm{~nm}\end{array}$ & $\begin{array}{l}\text { Rectangula } \\
\text { r shape }\end{array}$ & $\begin{array}{l}\text { Electrophor } \\
\text { etic } \\
\text { deposition } \\
\text { method }\end{array}$ & $\begin{array}{l}\text { UV-vis, FTIR, XRD, } \\
\text { SEM, EDAX, HRTEM }\end{array}$ & & $\begin{array}{l}\text { Shahram } \\
\text { Ghasemi et al } \\
(2015)^{57}\end{array}$ \\
\hline
\end{tabular}

Table 1. shows different methods, characterization and applications of CdO and MnO NPs. 
M. Vidhya et al (2017) successfully synthesized CdO NPs using a simple chemical precipitation approach. XRD, FESEM, UV-vis, and FTIR analysis validated the as-produced NPs. According to the FESEM investigation, $\mathrm{SnO}_{2}$ has a spherical morphology with no agglomeration, whereas $\mathrm{CdO}$ NPs have rod-shaped grains with highly agglomerated structures. The average crystallite size of CdO NPs was determined to be 23 $\mathrm{nm}$. Kannan $\mathbf{k}$ et al (2020) have successfully manufactured $\mathrm{CdO}$ nanocomposites utilizing a simple and effective microwave-assisted process. $\mathrm{CdO}$ nanocomposite crystal lattice structure was discovered to be cubic. The particle of the nanocomposites has a spherical form, and their size is $25 \mathrm{~nm}$. The Photocatalytic activity of the microwave-assisted $\mathrm{CdO}$ nanocomposites against $\mathrm{RB}$ dye was remarkable as was its antibacterial efficacy against human infections. Azam $\mathbf{Z}$ et al (2020) aimed to develop a simple, efficient, and cost-effective method for producing microbially mediated CdO-NPs. The research will be useful in explaining NPs creation in medication synthesis against resistant infection. The CdO NPs that have been created were spherical in shape, with an average crystalline size of $58 \mathrm{~nm}$. H. KohilaSubathra Christy et al (2020) synthesized CdO NPs utilizing cassia auriculata extract, which provides cost-effective, simple, and efficient techniques. The SEM image depicts a rod-like structure of produced CdO NPs with a particle size of $41 \mathrm{n}$. the temperature behaviour of CdO NPs is depicted by DSC, DTA, and TGA curves. The electro catalytic of produced CdO NPs is demonstrated by cyclic voltammeter measurements. Mohammed S. Alsaggaf et al (2020) synthesized CdO NPs by green approach from Aspergillus niger extract. The presence of spherical particles around $5 \mathrm{~nm}$ was discovered using scanning electron microscopy. Antimicrobial activity was found in the CdO NPs against E. coli, pseudomonas vulgaris. Staphylococcus aureus, and Bacillus subtilis. The biosynthesized CdO NPs show cytotoxic action against MCF7, PC3, and A549 cell lines, with 50\% inhibitory doses of 190g/ml, 246g/ml, and $149 \mathrm{~g} / \mathrm{ml}$ respectively. Ayman M. Mostafa et al (2017) successfully produce CdO NPs used laser ablation in a liquid environment with an average particle size of $24 \mathrm{~nm}$. A UV-vis spectrophotometer and an FTIR spectrophotometer were used to investigate the optical characterization. XRD was used to investigate the material structure, whereas FESEM, HRTEM, and EDX were used to investigate its morphological qualities. The creation of the $\mathrm{CdO}$ phase was confirmed by the experimental results of XRD and FTIR investigation. Naveed Akhtar Shad et al (2019) was employed to make CdO nanosheets by hydrothermal approach. The particle sizes are $28 \mathrm{~nm}$ in diameter and have a spherical form. The photodegradation effectiveness of the hazardous organic dye CBB has been successfully evaluated using CdO nanosheets. Irfan Ijaz et al (2020) synthesized CdO NPs from Calendula Officinalis. Several techniques, including UV-vis spectroscopy, FTIR, and SEM were used to analyze the nanoparticles. Similarly, UV absorbance at $300 \mathrm{~nm}$ was obtained, indicating that CdO NPs had been synthesized. In nanosynthesis, the photochemical serves as a capping agent. SEM is an abbreviation for scientific and engineering method SEM images revealed that the size of CdO NPs varied between 73-94 $\mathrm{nm}$. K. Karthik et al (2017) make CdO NPs by chelating agent A. paniculata via a biological approach. The cubic structure of the XRD pattern is seen and the nanoparticles are $164 \mathrm{~nm}$ on average, according to the FESEM image and HRTEM. EDS examination indicated the existence of Cd and O. Sumeet Kumar et al (2016) synthesized CdO NPs by hydrothermal method. Pure CdO and GO-CdO nanocomposites were studied for their structural, optical and magnetic properties, as well as Photocatalytic activity. The hydrothermal process is a good way to develop mono-disperse, stable, and dense CdO NPs on the GO sheets, according to the result of HRTEM and Raman studies. Eman A. Mwafy et al (2019) synthesized CdO NPs by pulsed laser ablation of Cd sheets immersed in functionlized MWCNTs solution, followed by cauterization employing various spectroscopic techniques such as IR, UV-vis, XRD, TEM, SEM and EDX. Under the influence of $\mathrm{CdO}$ NPs, mixing of MWCNTs and nano CdO vibration modes, bundles and spherical shape particles are attached with nanotubes of MWCNTs structure, crystallized rombohedral and face-centered cubic structures. Y N Permana et al (2017) synthesized CdO NPs using Parkiaspeciosa Hassk seed extract as the basic source and stabilizing agent. The direct band gap at $2.0 \mathrm{eV}$ was confirmed by UV-vis DRS measurements. The CdO bond was discovered in the range of $400-705 \mathrm{~cm}^{-1}$ in the FTIR spectrum. The XRD measurement revealed that the $\mathrm{CdO}$ structure is well formed in cubic phase, with typical nanocrystals sizes ranging between 28.92 and $44.95 \mathrm{~nm}$. Sourav Sadhukhan et al (2019) synthesized CdO NPs using dextrose as a reducing agent by green approach hydrothermal method, which is effective for removing oxygen functionalities from GO after reduction and makes a significant contribution to the accumulation of CdO NPs on the RGO sheets. HRTEM, XRD, XPS, AFM and BET analysis were used to explore the structural morphology and surface chemistry of $\mathrm{RGO} / \mathrm{CdO}$ nanocomposites, revealing a dense and homogeneous distribution of CdO NPs on RGO sheets. Synthesized CdO nanoparticles have a particle size of 3-4 $\mathrm{nm}$ and are spherical in shape. D. Durga Vijay karthik et al (2014) synthesized CdO NPs by using precipitation method. CdO NPs have an average crystallographic size of $39.73 \mathrm{~nm}$ and a spherical shape. FTIR, XRD, SEM with EDAX, and UV-vis measurement were used to characterize the produced nanoparticles, which demonstrated good antibacterial efficacy by preventing their growth. Demir E et al (2020) synthesized CdO NPs were both cytotoxic and genotoxic. In both TK6 and HepG2 cells, treatment with NPs reduced cell viability, decreased ATP content, and increased LDH leakage. In TK6 cells, the NPs caused DNA breaks and chromosomal damage, as well as 
mutations in murine lymphoma cells. These findings reveal the cytotoxicity and genotoxicity of CdO NPs in human and rodent cell lines, which can be used to determine the danger of CdO NPs. Javadkarimi Andeani et al (2013) synthesized CdO NPs using flower broth of A. wilhelmsii. UV-vis, FTIR, and FESEM were used to characterize these nanoparticles. We believe that tannins, flavonoids alkaloids and carotenoids were primarily responsible for the decrease in cadmium ions and the stabilization of the nanoparticles. The biological generation of $\mathrm{CdO}$ NPs has shown to be a simple, quick and environmentally friendly way for manufacturing $\mathrm{CdO}$ NPs at room temperature and extracellular without the need for further physical and chemical procedures. B. Goswami et al (2015) synthesized CdO NPs using a simple sol-gel synthesis process demonstrated luminescent capabilities in the visible region of the electromagnetic spectrum. The luminescence characteristics of cadmium interstitial vacancies and oxygen vacancies were both relevant. X-ray diffraction corroborated the morphological alteration caused by annealing. All of the experimental outcomes were found to be highly correlated. Diffuse reflectance spectra and photoluminescence spectra were used to examine optical characteristics. High-resolution transmission electron microscopy was used to evaluate structural characteristics. F.T. Thema et al (2015) demonstrated the green, innovative, and environmentally friendly synthesis of single phase highly crystalline $\mathrm{CdO}$ nanoparticles employing the natural extract of Agathosmabetulina's as an effective oxidizing/reducing chemical agent. HRTEM, EDS, XRF, XRD, ATR-FTIR, and XPS tests all show that a thermal annealing of $500^{\circ} \mathrm{C}$ for 2 hours under normal air circumstances results in well crystalline single phase $\mathrm{CdO}$ NPs. Harish Kumar et al (2013) used a green chemistry co-precipitation approach to $\mathrm{make}^{\mathrm{MnO}}$ nanoparticles with a simple cubic structure. The characteristics peaks of Mn-O stretching are revealed by FTIR spectral analysis. Metal nanoparticles cause a sharp absorption at $339.60 \mathrm{~nm}$ in the UV-visible spectrum. The average size predicted by XRD spectra is 25-30 nm. Elsa Cherian et al (2016) used the co-precipitation approach to make manganese dioxide nanoparticles. The existence of manganese dioxide nanoparticles was confirmed using UV-vis spectroscopy. The FTIR spectrum findings show the manganese dioxide nanoparticles peculiar peaks. SEM investigation revealed a spherical shape with a diameter ranging from 40.5-70 nm. Synthesized manganese dioxide nanoparticles can be employed as an antibacterial agent. Keerthana Sivanesan et al (2017) synthesized MnO NPs from the Aegle marmelos fruit extract in a more environmentally friendly method. The average crystallite size of the produced nanoparticles was $23.7 \mathrm{~nm}$. The maximum activity against E.coli was 1.2170 .43 at $80 \mathrm{~g} / \mathrm{ml}$, and the highest activity against B.subtilis was 1.7050 at $100 \mathrm{~g} / \mathrm{ml}$. The maximum activity of nanoparticles against reactive oxygen species was reported to be 27.310 at a dose of 5 $\mathrm{mg} / \mathrm{ml}$. Taimurathar et al (2012) synthesized MnO NPs were created using a soft chemical technique with regulated morphological and surface particle properties, with a size of roughly $33 \mathrm{~nm}$. Synthetically and physically well defined particles allow for a better grasp of knowledge and structural qualities, which aids in the development of future applications. FTIR, UV-vis, TGA/DSC, XRD, SEM-EDX, TEM, and BET were used to characterize the nanoparticles as they were produced. Vikas kumar Verma et al (2018) synthesized MnO NPs from solid state process. X-ray diffraction, scanning electron microscopy, and UV-vis absorption spectroscopy were used to analyze the produced material. The addition of $\mathrm{MnO}_{2}$ to $\mathrm{Zn}$ increased crystallization and reduced crystallite size. The hexagonal sized particles were uniformly distribution in zinc oxide, leaving a large number of pores. These pores served as adsorption sites for moisture, for 1.0 weight $\% \mathrm{MnO}_{2}$ doped zinc oxide, the minimum average crystallite size was $31.7 \mathrm{~nm}$. NurOktriMulyaDewi et al (2020) synthesized MnO NPs by green synthesis approach employing Euphorbia heterophylla leaves extract. FTIR at $559 \mathrm{~cm}^{-1}$ wave number revealed chemical bonding of Mn-O. Particle size analyser measurement revealed that the particle size of $\mathrm{MnO}_{2}$ NPs was around $56.68 \mathrm{~nm}$. TheUV-vis DRS spectrophotometer confirmed that the band gap energy of $\mathrm{MnO}_{2}$ NPs was $2.85 \mathrm{eV}$. SEM, XRD, and TEM were used to confirm the morphology of $\mathrm{MnO}_{2} \mathrm{NPs}_{\text {. }} \mathrm{MnO}_{2} \mathrm{NPs}$ was found to have an uneven form using an electron microscope. Naveen Chandra Josh et al (2020) synthesized MnO NPs by green synthetic technique utilizing A.vera extract was found to be very low cost, efficient, and nontoxic. The FTIR, XRD, and FESEM procedures were used to characterize the recently produced $\mathrm{MnO}_{2} \mathrm{NPs}_{\text {. }}$ $\mathrm{MnO}_{2} \mathrm{NPs}$ discovered to have greater antibacterial action. Yilkal Dessie et al (2020) synthesized MnO NPs using a biosynthetic process under 25 distinct physiochemical conditions, including the ratio of V. Amygdalina leaf extract, beginning permanganate ion concentration. $\mathrm{pH}$, and reaction duration. XRD research revealed that the average size was between 20-22 nm. According to SEM examination, $\mathrm{MnO}_{2} \mathrm{NPs}$ synthesized under ideal conditions with plant extract as a reducing agent created a better porous image with nanosphericl flower like topograph. Mahsa Souri et al (2018) synthesized MnO NPs as a reducing and stabilizing agent with Y. Gloriosa leaf extract and turmeric extract. XRD, FESEM, and TEM studies were used to characterize the $\mathrm{MnO}_{2}$ NPs. The $\mathrm{MnO}_{2}$ NPs were produced with a size of roughly $32 \mathrm{~nm}$, according to XRD examination. Plant extract synthesis is possible with a simple reaction at room temperature and pressure, without the use of catalysts, casts or expensive materials. R.Manjula et al (2019) synthesized MnO NPs from G. Resinifera leaf extract and characterize them. UV-vis, PSA, SEM-EDAX, XRD, and HRTEM analysis were used to evaluate the produced $\mathrm{MnO}_{2}$ NPs. According to the findings, the produced $\mathrm{MnO}_{2}$ NPs are 17-35 nm in diameter and spherical in form. The findings of the FTIR analysis reveal the presence of numerous functional groups that could be involved in diverse biological functions. The antibacterial activity of the produced $\mathrm{MnO}_{2} \mathrm{NPs}$ is strong. A K M Atique 
Ullah et al (2018) synthesized MnO NPs from a simple green synthesis technique for the production of crystalline- $\mathrm{MnO}_{2} \mathrm{NPs}$ with diameters ranging from 4-18 nm. The method for making $\mathrm{MnO}_{2}$ nanocrystals is easy, environmentally friendly, cost-effective, and efficient and it does not require any external reducing agents or stabilizers. The magnetic properties of $\mathrm{MnO}_{2} \mathrm{NPs}$ prepared by this method were investigated using a vibrating sample magnetometer at room temperature, and the VSM analysis revealed a small hysteresis loop, indicating that the bio-molecule capped $\mathrm{MnO}_{2} \mathrm{NPs}$ have a weak ferromagnetic property. Veeman Sannasi et al (2020) synthesized $\mathrm{MnO}$ NPs by two crystallographic phases of $\mathrm{MnO}_{2}, \mathrm{a}-\mathrm{MnO}_{2}$ and b- $\mathrm{MnO}_{2}$ respectively. The materials were analyzed using SEM and TEM and revealed nanocrystals morphology for a- $\mathrm{MnO}_{2}$ and nanorod morphology for b- $\mathrm{MnO}_{2}$. Adina Stegarescu et al (2019) synthesized MnO NPs from the surface area of biochemically generated was four times that of chemically generated nanoparticles. $\mathrm{MnO}_{2}$ oregano had the biggest crystalline core $(3.4 \mathrm{~nm})$, the biggest pore volume $\left(0.77 \mathrm{~cm}^{3} / \mathrm{g}\right)$, the biggest surface area $\left(398 \mathrm{~m}^{2} / \mathrm{g}\right)$, and the most $\mathrm{Mn}$ ions in low oxidation states. For these reasons, biochemically produced $\mathrm{MnO}_{2} \mathrm{NPs}$ were evaluated for microwave-assisted Trans esterification of grape residue and seeds oil, as well as yeast to get a biofuel end product efficiently.Sheng Chen et al (2010) synthesized MnO NPs by a grapheme oxide composite supported by needle like in a water isopropyl alcohol solution using a simple soft chemical method. Intercalation and adsorption of manganese ions onto the GO sheets, followed by crystallization of the crystal species in a double solvent system via dissolution crystallization and oriented attachment mechanism, is proposed as the formation mechanism of these intriguing nanocomposites studied by TEM, Raman, and UV-vis spectroscopy. Shahram Ghasemi et al (2015) synthesized MnO NPs using the electrophoretic deposition approach. After that, an electrochemical reduction process is used to reduce the grapheme oxide coating. For the deposition of $\mathrm{MnO}_{2}$ or ERGO, a two step potential approach and anodic electro deposition approach have been devised. Two potential steps have been used to nucleate and develop manganese oxide on graphene sheets, resulting in homogeneous dispersion of $\mathrm{MnO}_{2} \mathrm{NPs}$ decorated onto ERGO.

\section{Conclusion:}

CdO NPs and MnO NPs provide a wide range of possible uses due to their unique properties. In this paper we describe how we have been able to encourage progress in $\mathrm{Cd}$ and $\mathrm{Mn}$ with antibacterial, antimicrobial, Photocatalytic, antibiofilm and antioxidant activities. There have been a number of configurable systems built for large-scale application.

\section{Acknowledgement:}

The authors are thankful to Maharishi Markandeshwar (Deemed to be) University, Mullana, Ambala (Haryana).

\section{References:}

[1] Burda, Clemens, Xiaobo Chen, Radha Narayanan, and Mostafa A. El-Sayed. "Chemistry and properties of nanocrystals of different shapes", Chemical reviews .,105, no. 4, (2005), 1025-1102.

[2] Cherian, Elsa, Arya Rajan, and G. Baskar. "Synthesis of manganese dioxide nanoparticles using coprecipitation method and its antimicrobial activity", International Journal of Modern Science and Technology., 1, no. 01, (2016), 17-22.

[3] Athar, Taimur, Neha Topnani, Abdul Hakeem, and Waqar Ahmed. "Synthesis and characterization of MnO2 and CdO nanoparticles," Advanced Science Letters.,7, no. 1, (2012), 39-42.

[4] Cheng, Fangyi, Jian Shen, Bo Peng, Yuede Pan, Zhanliang Tao, and Jun Chen. "Rapid room-temperature synthesis of nanocrystalline spinels as oxygen reduction and evolution electrocatalysts," Nature chemistry.,3, no. 1, (2011), 79-84.

[5] Wang, Xun, and Yadong Li. "Synthesis and formation mechanism of manganese dioxide nanowires/nanorods," Chemistry-A European Journal., 9, no. 1, (2003), 300-306.

[6] Ching, Stanton, Eric J. Welch, Steven M. Hughes, Adilah BF Bahadoor, and Steven L. Suib. "Nonaqueous sol- gel syntheses of microporous manganese oxides," Chemistry of materials., 14, no. 3, (2002),1292-1299.

[7] Oaki, Yuya, and Hiroaki Imai. "One-pot synthesis of manganese oxide nanosheets in aqueous solution: chelation-mediated parallel control of reaction and morphology," Angewandte Chemie International Edition.,46, no. 26, (2007), 4951-4955. 
[8] Yu, X. Q., Y. He, J. P. Sun, K. Tang, H. Li, L. Q. Chen, and X. J. Huang. "Nanocrystalline MnO thin film anode for lithium ion batteries with low overpotential," Electrochemistry Communications., 11, no. 4, (2009), 791-794.

[9] Ahmad, Tokeer, Kandalam V. Ramanujachary, Samuel E. Lofland, and Ashok K. Ganguli. "Nanorods of manganese oxalate: a single source precursor to different manganese oxide nanoparticles (MnO, Mn 2 O 3, Mn 3 O 4)," Journal of Materials Chemistry., 14, no. 23, (2004), 3406-3410.

[10] Hoseinpour, Vahid, and Nasser Ghaemi. "Green synthesis of manganese nanoparticles: Applications and future perspective-A review," Journal of Photochemistry and Photobiology B: Biology.,189, (2018), $234-243$.

[11] Vidhya, M., R. Archana, K. Sadayandi, Sagadevan Suresh, S. Gunasekaran, Jiban Podder, Faruq Mohammad, Hamad A. Al-Lohedan, and Won Chun Oh. "Comparison of sunlight-driven photocatalytic activity of semiconductor metal oxides of tin oxide and cadmium oxide nanoparticles." Optik.,217, (2020), 164878.

[12] Thambidurai, Mariyappan, and Cuong Dang. "Structural, morphological and optical properties of CdO nanostructures synthesized by chemical bath deposition method," Materials Letters.,221, (2018), 244-247.

[13] Karthik, K., S. Dhanuskodi, C. Gobinath, S. Prabukumar, and S. Sivaramakrishnan. "Multifunctional properties of $\mathrm{CdO}$ nanostructures Synthesised through microwave assisted hydrothermal method," Materials Research Innovations., 23, no. 5, (2019), 310-318.

[14] Krishnakumar, T., R. Jayaprakash, T. Prakash, D. Sathyaraj, N. Donato, S. Licoccia, M. Latino, A. Stassi, and G. Neri. "CdO-based nanostructures as novel CO2 gas sensors," Nanotechnology., 22, no. 32, (2011), 325501 .

[15] Zhai, Tianyou, Xiaosheng Fang, Meiyong Liao, Xijin Xu, Haibo Zeng, Bando Yoshio, and Dmitri Golberg. "A comprehensive review of one-dimensional metal-oxide nanostructure photodetectors," Sensors., 9, no. 8, (2009), 6504-6529.

[16] Minami, Tadatsugu. "Transparent conducting oxide semiconductors for transparent electrodes," Semiconductor science and technology., 20, no. 4, (2005), S35.

[17] Yakuphanoglu, Fahrettin. "Nanocluster n-CdO thin film by sol-gel for solar cell applications," Applied Surface Science., 257, no. 5, (2010), 1413-1419.

[18] Heidari, Alireza, and Christopher Brown. "Study of composition and morphology of cadmium oxide (CdO) nanoparticles for eliminating cancer cells," Journal of Nanomedicine Research., 2, no. 5, (2015), 20.

[19] Shukla, M., S. Kumari, S. Shukla, and R. K. Shukla. "Potent antibacterial activity of nano CdO synthesized via microemulsion scheme," J. Mater. Environ. Sci.,3, no. 4, (2012), 678-685.

[20] Guo, Zheng, Minqiang Li, and Jinhuai Liu. "Highly porous CdO nanowires: preparation based on hydroxyand carbonate-containing cadmium compound precursor nanowires, gas sensing and optical properties," Nanotechnology., 19, no. 24, (2008), 245611.

[21] Rahman, Mohammed M., Abdullah M. Asiri, Tamer E. Youssef, and Hadi M. Marwani. "Photocatalytic degradation of remazol brilliant orange 3R using wet-chemically prepared $\mathrm{CdO}-\mathrm{ZnO}$ nanofibers for environmental remediation," Materials Express., 6, no. 2, (2016), 137-148.

[22] Heidari, Alireza, and Christopher Brown. "Study of composition and morphology of cadmium oxide (CdO) nanoparticles for eliminating cancer cells," Journal of Nanomedicine Research., 2, no. 5, (2015), 20.

[23] Yekta, S., and M. Sadeghi. "Preparation of the novel zeolite AgX/CdO NPs composite catalyst and its appli-cation for the effective removal of fenitrothion (FN) from water," Int. J. Bio-Inorg. Hybr. Nanomater., 7, no. 1 , (2018), 29-42.

[24] Yekta, S., and M. Sadeghi. "Preparation of the novel zeolite AgX/CdO NPs composite catalyst and its appli-cation for the effective removal of fenitrothion (FN) from water," Int. J. Bio-Inorg. Hybr. Nanomater., 7, no. 1, (2018), 29-42. 
[25] Vidhya, M., R. Archana, K. Sadayandi, Sagadevan Suresh, S. Gunasekaran, Jiban Podder, Faruq Mohammad, Hamad A. Al-Lohedan, and Won Chun Oh. "Comparison of sunlight-driven photocatalytic activity of semiconductor metal oxides of tin oxide and cadmium oxide nanoparticles," Optik., 217, (2020), 164878.

[26] Kannan, Karthik, D. Radhika, Maria P. Nikolova, V. Andal, Kishor Kumar Sadasivuni, and L. Sivarama Krishna. "Facile microwave-assisted synthesis of metal oxide $\mathrm{CdO}-\mathrm{CuO}$ nanocomposite: photocatalytic and antimicrobial enhancing properties," Optik.,218,(2020), 165112.

[27] Azam, Zara, Asma Ayaz, Muhammad Younas, Zeeshan Qureshi, Bushra Arshad, Wajid Zaman, Fazal Ullah et al. "Microbial synthesized cadmium oxide nanoparticles induce oxidative stress and protein leakage in bacterial cells," Microbial pathogenesis., 144, (2020), 104188.

[28] Christy, H. Kohila Subathra, P. Gurulakshmi, D. Shanmuga Priya, and C. Stella. "Electrochemical and Thermal Behaviour of Cadmium Oxide Nanoparticles."

[29] Alsaggaf, Mohammed S., Ashraf F. Elbaz, El Badawy, and Shaaban H. Moussa. "Anticancer and antibacterial activity of cadmium sulfide nanoparticles by Aspergillus niger," Advances in Polymer Technology., 2020 (2020).

[30] Mostafa, Ayman M., Samir A. Yousef, Wael H. Eisa, Mahmoud A. Ewaida, and Emad A. Al-Ashkar. "Synthesis of cadmium oxide nanoparticles by pulsed laser ablation in liquid environment," Optik., 144, (2017), 679-684.

[31] Shad, Naveed Akhtar, M. Munir Sajid, Akram-Ul Haq, Nasir Amin, Zahid Imran, Hafeez Anwar, Khuram Ali, Zajif Hussain, Ayesha Younus, and Yasir Javed. "Photocatalytic investigation of cadmium oxide nanosheets prepared by hydrothermal method," Arabian Journal for Science and Engineering., 44, no. 7, (2019), 6669-6675.

[32] Ijaz, Irfan, Ezaz Gilani, Ammara Nazir, Aysha Bukhari, and Jahanzaib Ahmad Ansari. Green Synthesis, Characterization and Antibacterial Activity of Cadmium Oxide Nanoparticles Using Calendula Officinali'S Plant. No. 2453. EasyChair, 2020.

[33] Karthik, K., S. Dhanuskodi, C. Gobinath, S. Prabukumar, and S. Sivaramakrishnan. "Andrographis paniculata extract mediated green synthesis of $\mathrm{CdO}$ nanoparticles and its electrochemical and antibacterial studies," Journal of Materials Science: Materials in Electronics., 28, no. 11, (2017), 7991-8001.

[34] Kumar, Sumeet, Animesh K. Ojha, and Bernd Walkenfort. "Cadmium oxide nanoparticles grown in situ on reduced graphene oxide for enhanced photocatalytic degradation of methylene blue dye under ultraviolet irradiation," Journal of Photochemistry and Photobiology B: Biology., 159, (2016), 111-119.

[35] Mwafy, Eman A., and Ayman M. Mostafa. "Multi walled carbon nanotube decorated cadmium oxide nanoparticles via pulsed laser ablation in liquid media," Optics \& Laser Technology., 111, (2019), 249-254.

[36] Permana, Y. N., and Yoki Yulizar. "Potency of Parkia speciosa Hassk seed extract for green synthesis of $\mathrm{CdO}$ nanoparticles and its characterization," In IOP conference series: Materials science and engineering., vol. 188, no. 1, (2017), p. 012018.

[37] Sadhukhan, Sourav, Tapas Kumar Ghosh, Indranil Roy, Dipak Rana, Amartya Bhattacharyya, Rajib Saha, Sanatan Chattopadhyay, Somanjana Khatua, Krishnendu Acharya, and Dipankar Chattopadhyay. "Green synthesis of cadmium oxide decorated reduced graphene oxide nanocomposites and its electrical and antibacterial properties," Materials Science and Engineering: C., 99 (2019), 696-709.

[38] DurgaVijaykarthik, D., M. Kirithika, N. Prithivikumaran, and N. Jeyakumaran. "Synthesis and characterization of cadmium oxide nanoparticles for antimicrobial activity," International Journal of Nano Dimension., 5, no. 6, (2014), 557-562.

[39] Demir, Eşref, Taichun Qin, Yan Li, Yongbin Zhang, Xiaoqing Guo, Taylor Ingle, Jian Yan et al. "Cytotoxicity and genotoxicity of cadmium oxide nanoparticles evaluated using in vitro assays," Mutation Research/Genetic Toxicology and Environmental Mutagenesis., 850,(2020), 503149. 
[40] Karimi Andeani, Javad, and Sasan Mohsenzadeh. "Phytosynthesis of cadmium oxide nanoparticles from Achillea wilhelmsii flowers," Journal of Chemistry.,2013, (2013).

[41] Goswami, B., and A. Choudhury. "Enhanced visible luminescence and modification in morphological properties of cadmium oxide nanoparticles induced by annealing," Journal of experimental nanoscience.,10, no. 12, (2015), 900-910.

[42] Thema, F. T., P. Beukes, A. Gurib-Fakim, and M. Maaza. "Green synthesis of Monteponite CdO nanoparticles by Agathosma betulina natural extract," Journal of Alloys and Compounds.,646, (2015): 10431048 .

[43] Sahib, Rasha S., and Juman A. Naser. "Preparation, Characterization and Surface Area Properties of Manganese Oxide Nanoparticles," Annals of the Romanian Society for Cell Biology., (2021), 2962-2969.

[44] Sahib, Rasha S., and Juman A. Naser. "Preparation, Characterization and Surface Area Properties of Manganese Oxide Nanoparticles." Annals of the Romanian Society for Cell Biology (2021): 2962-2969.

[45] Cherian, Elsa, Arya Rajan, and G. Baskar. "Synthesis of manganese dioxide nanoparticles using coprecipitation method and its antimicrobial activity," International Journal of Modern Science and Technology., 1, no. 01, (2016), 17-22.

[46] Sivanesan, Keerthana, Priyanga Jayakrishnan, Sirajunnisa Abdul Razack, Pavithra Sellaperumal, Geethalakshmi Ramakrishnan, and Renganathan Sahadevan. "Biofabrication of manganese nanoparticle using Aegle marmelos fruit extract and assessment of its biological activities," Nanomedicine Research Journa.,l 2 , no. $3,(2017), 171-178$.

[47] Athar, Taimur, Neha Topnani, Abdul Hakeem, and Waqar Ahmed. "Synthesis and characterization of MnO2 and CdO nanoparticle,"Advanced Science Letters., 7, no. 1, (2012), 39-42.

[48] Verma, Vikas Kumar, and Narendra Kumar Pandey. "MnO 2-ZnO hexagonal nanomaterials: characterization and high performance humidity sensing application," International Journal of Scientific Research in Physics and Applied Sciences., 6, no. 6, (2018), 69-79.

[49] Dewi, Nur Oktri Mulya, and Yoki Yulizar. "Euphorbia heterophylla L. leaf extract-mediated synthesis of MnO2 nanoparticles and its characterization," Materials Today: Proceedings., 22 (2020), 199-204.

[50] Joshi, Naveen Chandra, Faisal Siddiqui, Mohd Salman, and Ajay Singh. "Antibacterial Activity, Characterizations, and Biological Synthesis of Manganese Oxide Nanoparticles using the Extract of Aloe vera," Asian Pacific Journal of Health Sciences., 7, no. 3, (2020), 27-29.

[51] Souri, Mahsa, Vahid Hoseinpour, Nasser Ghaemi, and Alireza Shakeri. "Procedure optimization for green synthesis of manganese dioxide nanoparticles by Yucca gloriosa leaf extract," International Nano Letters., 9, no. 1, (2019),73-81.

[52] Manjula, R., M. Thenmozhi, S. Thilagavathi, R. Srinivasan, and A. Kathirvel. "Green synthesis and characterization of manganese oxide nanoparticles from Gardenia resinifera leaves," Materials Today: Proceedings 26., (2020),3559-3563.

[53] Ullah, AKM Atique, Md Mahbubul Haque, Mahmuda Akter, A. Hossain, A. N. Tamanna, Md Mottaleb Hosen, AKM Fazle Kibria, M. N. I. Khan, and M. K. A. Khan. "Green synthesis of Bryophyllum pinnatum aqueous leaf extract mediated bio-molecule capped dilute ferromagnetic $\alpha-\mathrm{MnO} 2$ nanoparticles," Materials Research Express.,7, no. 1, (2020), 015088.

[54] Sannasi, Veeman, and Karuppuchamy Subbian. "Influence of Moringa oleifera gum on two polymorphs synthesis of $\mathrm{MnO} 2$ and evaluation of the pseudo-capacitance activity," Journal of Materials Science: Materials in Electronics., 31, no. 19, (2020), 17120-17132.

[55] Stegarescu, Adina, Ildiko Lung, Cristian Leoștean, Irina Kacso, Ocsana Opriș, Mihaela Diana Lazăr, Lucian Copolovici et al. "Green Synthesis, Characterization and Test of MnO 2 Nanoparticles as Catalyst in Biofuel Production from Grape Residue and Seeds Oil," Waste and Biomass Valorization.,(2019), 1-11. 
[56] Chen, Sheng, Junwu Zhu, Xiaodong Wu, Qiaofeng Han, and Xin Wang. "Graphene oxide- MnO2 nanocomposites for supercapacitors," ACS nano 4, no. 5,(2010), 2822-2830.

[57] Ghasemi, Shahram, Rahman Hosseinzadeh, and Majid Jafari. "MnO2 nanoparticles decorated on electrophoretically deposited graphene nanosheets for high performance supercapacitor,.," International Journal of hydrogen energy., 40, no. 2, (2015), 1037-1046. 